ISSN 2080-1653

DOI 10.24917/20801653.324.4

\author{
WIOLETTA KILAR \\ Pedagogical University of Cracow, Poland
}

\title{
Corporations as an Object of Research in Geography of Industry
}

\begin{abstract}
Today, corporations play an important role in the global, national and local economy. Regardless of the business profile, degree of internationalisation or size, they participate in numerous economic processes, which is why they are the subject of research in geography of industry, especially in geography of enterprises. The main goal of the article is to review research related to corporations in Polish literature on the subject in the field of geography of industry. The author also aims at organising the concept of corporations, presenting closer their classifications, as well as indicating the place of research on corporations in geography. The preparation of the article began with a literature query, as well as an analysis of the existing data (desk research). As a result, the analysis of the concept of a corporation, various types of classifications and divisions of corporations, as well as a literature review of the subject in terms of the corporation's research issues were made. As the research carried out indicates, in Polish literature on the issues of geography of industry, the researchers who concentrate on corporations look at the concentration of their head offices, theory and location factors, shaping processes and location of production, service and various branches, network connections, strategies implemented by corporations and their organisational forms, processes of corporation influence on international conditions for the development of domestic and regional systems and industrial enterprises, stimulation of inflow of foreign direct investment, the influence of corporations on the shaping of various industrial sectors, export relations, the role of cities in globalisation processes and the location of the corporation and their effects, as well as on corporate CSR activities.
\end{abstract}

Keywords: corporation; geography of enterprise; geography of industry; international company

Received: 15 July 2018

Accepted: 16 August 2018

\section{Suggested citation:}

Kilar, W. (2018). Corporations as an Object of Research in Geography of Industry. Prace Komisji Geografii Przemysłu Polskiego Towarzystwa Geograficznego [Studies of the Industrial Geography Commission of the Polish Geographical Society], 32(4), 69-85. https://doi.org/10.24917/20801653.324.4

\section{INTRODUCTION}

Corporations, due to their significant potential, are an important driving force in global economy. Other factors affecting their growing role are primarily capital held, management by highly qualified managerial groups, own dynamic research and development centres, as well as various branches. 
Corporations, regardless of the profile of their activities, have an indirect and direct impact on the society of almost every country. Therefore, among other entities in the economy, corporations are the theme of study of many sciences, including geography.

The main goal of the article is to review the research related to corporations in Polish literature on the subject in the field of geography of industry. The author discusses the concept of a corporation, analyses the classification of corporations, and aims to indicate the place of research on corporations in geographical surveys.

Research work was based on basic methods, i.e. query and analysis of the subject literature, as well as analysis of existing data (desk research).

\section{THE CONCEPT OF A CORPORATION}

The growing interest in the activities of large enterprises operating internationally was most significant in the 1970s. In the literature on the subject, transnational corporations are most often treated as enterprises, companies, international firms, multinational firms, or transnational firms.

One of the earliest definitions of a corporation, as indicated by A. Zorska (2007: 123), was formulated by P.J. Buckley and M. Casson (1976). The authors assume that it is an enterprise that owns and controls operations in various countries. Discussing the various types of market distortions and transaction costs, they point to the only effective way to mitigate their effects by establishing common ownership and control of corporations over activities abroad. The attribute of a corporation is, therefore, the ability to bypass market distortions and reduce transaction costs of operations by internationalising activities carried out in its own structure in different countries.

In 1974, the UN report entitled "The Impact of Multinational Corporations on Development and International Relations", regarding the impact of these entities' activities on development and international relations, multinational corporations are defined as enterprises who own or have control over production or service units located outside the country of the head office. It is recognised that "these enterprises may be companies or units with private capital, but also mixed or state capital" (after Jarczewska-Romaniuk, 2004: 18).

Since the 1970s, the activities of these large enterprises have been an important subject of the United Nations Conference for Trade and Development (UNCTAD). The result of this organisation's activities are annual reports (WIR - World Investment Report, $2005,2006)$, which have adopted the concept of a transnational corporation, defined as "an enterprise being a joint-stock company or other business entity consisting of a parent enterprise (with control over at least $10 \%$ of shares or other shares over economic units located outside its country of origin) and foreign enterprises affiliated to it, which include: subsidiaries, in which $50 \%$ of shares or other resources are controlled by a parent undertaking; affiliates, 10 to $50 \%$, respectively; and branches, wholly under the control of the parent company, 100\% of shares" (World Investment Report, 2001: 275).

In parallel with the work carried out by the UN, the issues of the corporation's activities were taken up by the Organization for Economic Cooperation and Development (OECD). In 1974, in the Declaration on International Investments and Multinational Enterprises, multinational enterprises were defined as: "companies or other entities with private, state or mixed capital located in different countries and interrelated in such a way that each separately or jointly can exert a significant influence on the activities of 
others, in particular, share knowledge and resources with them" (after Jarczewska-Romaniuk, 2004: 19).

E. Czarny (Czarny, Kleinert, 2004: 234-235) emphasises that one of the manifestations of internationalisation of economic processes is the expansion of multinational enterprises. He defines them as: "companies owning enterprises or controlling economic activity in more than one country".

A. Zorska (2007) explains that there are two names in English literature at the same time: multinational enterprises (MNEs) or multinationals, and transnational corporations (TNCs), assuming that transnational corporations are enterprises operating across national borders. Finally, A. Zorska (2007: 10) adopts the concept of transnational corporations (TNCs) after the United Nations, defining them as "enterprises whose activity permeates national borders and is organised, integrated and coordinated by the head office in the home country".

J.H. Dunning, who from the mid-1970s conducted his research on corporate issues in the United States and mainly focused on corporate operations in foreign direct investment (FDI), defines that a corporation is an enterprise that engages in foreign direct investment and owns and controls the activity of units creating added value in more than one country (after Zorska, 2007: 123).

A. Zorska (2002: 50), after J.H. Dunning (1993), emphasises that the main and unique feature of corporations is their involvement in international production in other countries and trading in intermediate goods (creating this production) on the markets of these countries, within their own organisational structures.

P. Dicken (1992) formulates the definition of a transnational corporation, in which he points out that it is an organisation that coordinates and controls operational activities in more than one country, even if the resources are not its property (Jarczewska-Romaniuk, 2004: 20). He believes that its own specialised value-creating activities are complemented by contracted activities carried out by external, independent companies located in different countries. In connection with this, cross-border networks of internal and external relations are created, which are driven by the ability to integrate and coordinate geographically and organisationally dispersed activities by corporations. P. Dicken emphasises that a corporation making decisions from one centre creates the added value of different units in different countries. The centre is usually the head office of the parent corporation, although in the case of the largest corporations some of the competencies are transferred to regional offices that oversee the activities of more regions (Zorska, 1998, 2007).

Therefore, the author, for the purpose of this study, adopts the concept of a corporation by P. Dicken, considering that it is one of the most complete definitions. At the same time, it confirms A. Zorska's view that transnational corporations are currently the most powerful and most thriving organisations in the world (Zorska, 1998, 2002, 2007).

The problem of defining corporations is widely analysed in the literature, in which the concept of corporations is understood in a similar way. The word "corporation" in Polish law distinguishes a company that is a "joint stock company", but in the national literature, adjectives specifying a corporation, e.g. transnational, global, are usually used interchangeably. Therefore, it seems particularly important to approximate the classification of corporations used in the literature on the subject, delimited due to different criteria of division. 


\section{DELIMITATION OF CORPORATIONS IN THE LITERATURE OF THE SUBJECT}

The subject matter of corporations in the specialist literature also includes delimitation of corporations and adopts various criteria. In addition to the delimitation based on the subject of the business, which distinguishes the following corporations: production (manufacturing and processing sector), service (trade, finance, insurance and others) and diversified activities (conducting their activities simultaneously in many industries, e.g. General Electric corporation), the classification which is often referred to and which deserves special attention, takes as a criterion the degree of internationalisation and the structure of the corporation.

\section{Division of corporations due to the degree of internationalisation}

Internationalisation is a complex process that J. Kukułka (2000) defines as a continuous and ascending process of internationalisation, i.e. going beyond the national borders of various elements of economy, politics, culture, science, technology, information, services, sport, entertainment, and customs. In economic sense, it is understood as a kind of economic activity undertaken by a company abroad, but it has a phase character, and subsequent phases may or may not occur. Considering, as a criterion for the division of corporations, the degree of internationalisation, the literature includes different divisions of corporations. In general, the successive stages which a given enterprise enters, by internationalising its operations, constitute types of corporations in the classifications. R. Griffin (1998) and H. Towarnicka (1997) attempted to systematise corporations by adopting this criterion. R. Griffin divides enterprises into national, international, multinational, and global, while H. Towarnicka distinguishes national, export, international, multinational, transnational, and supranational. The key role in classifying a company to the category is played by the organisation and management model adopted by them.

A. Jarczewska-Romaniuk (2004) analyses adjectives specifying corporations in terms of internationalisation. She assumes that international corporations are those that operate in different countries (nations) and have representatives in many countries; transnational corporations concern all countries (nations) and are superior to all nations; while international and multinational terms are, according to her, synonymous. The term 'transnational' is understood by the author as a company operating across national borders, and their activity based on a constant and conscious undertaking of actions going beyond national borders and establishing wide international contacts, thus exerting an influence on international relations.

W. Gierańczyk and A. Stańczyk (2003) recognise that if the company's assets are located in at least two countries, the corporation will be called 'international'. The authors emphasise that internationalisation can be measured by the percentage of sales for export, the share of foreign workforce employed abroad, in the value of assets abroad, the share of foreign production in total production or the profit generated from foreign operations. By accepting these criteria, the authors, after J. Czupiał (1997), divide corporations, similarly to $\mathrm{H}$. Towarnicka, into international, multinational, transnational, and supranational (global) and made their detailed characterisation (Tab. 1). 


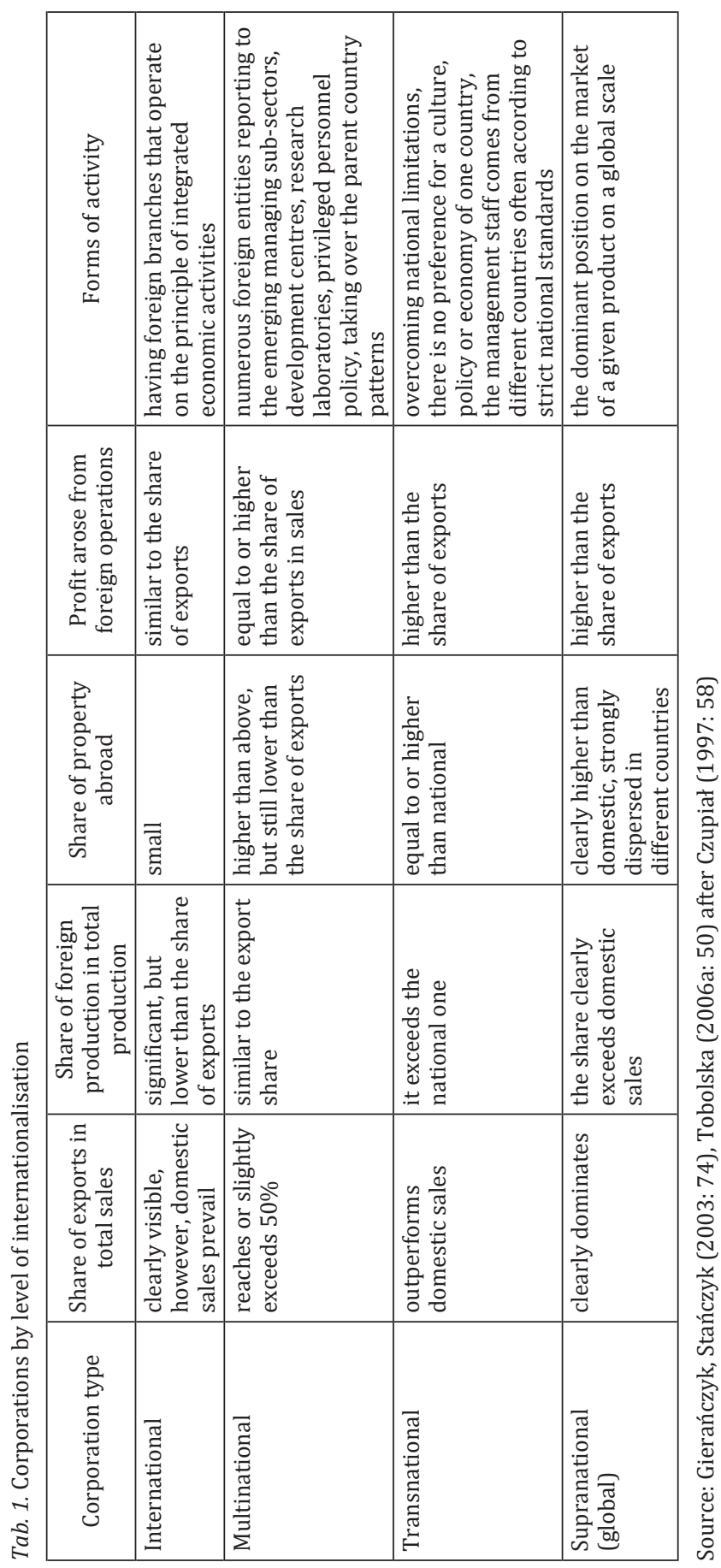


In the literature on the subject, some authors use the UNCTAD transnationality index, calculated as the arithmetic mean of three factors: transnationalisation of assets (value of foreign assets to the value of all assets), sales (quotient of the value of foreign sales to the total value of sales) and employment (the ratio of the number of employees abroad to general employment). The ratio is expressed as a percentage, and its values range from 0 to $100 \%$, with values close to $100 \%$ indicating the huge scale of foreign involvement of a given corporation (World Investment Report, 2001; Jarczewska-Romaniuk, 2004; Marzęda, 2007). Due to the degree of internationalisation of activity measured by the transnationalisation index, we distinguish corporations with high internationalisation rate (significantly dependent on foreign activity, most of the enterprise's operations are carried out outside the country of origin) and low rate (low dependence on foreign activity, most of the company's activities are carried out in the country of origin) (Jarczewska-Romaniuk, 2004: 83). Most often, this indicator is used for analyses of the activities of production corporations, but no such assessment has been made for financial corporations, e.g. banks (Tobolska, Matykowski, 2006).

\section{Division due to the corporate structure}

Due to the corporate development process resulting from establishing branches in various countries, the following are distinguished:

- vertical corporations, in which production is divided into stages located in different places (countries) in order to minimise costs; corporations of this type often make direct investments in developing countries,

- horizontal corporations, which are multi-plant companies that develop similar activities in different places, while maintaining uniform control over multiple production units; subsequent corporations start to develop when benefits arise from the location of production in different countries, from lowering transaction costs or management costs, or when the parent company has specific competitive assets (often immaterial); such corporations deal with both production and service activities,

- conglomerates, or corporations with diversified activities; the production of individual branches is neither interrelated horizontally nor vertically; they are created to differentiate the risk resulting from the company's operations (Czarny, Kleinert, 2004).

Thus, individual corporate taxonomies, created on the basis of various criteria, are complementary, not competitive, and individual corporations may at the same time be included in many classifications.

\section{THE PLACE OF THE CORPORATION IN GEOGRAPHY OF INDUSTRY}

The issue of corporations is the subject of research in many scientific disciplines, mainly economic and geographic sciences. In geography, the issues analysed belong to geography of enterprise, i.e. one of the currents of geography of industry, part of economic geography. Modern geography of industry is eclectic, because it is assumed - after R. Hayter (1997) - that the boundaries between theories get blurred, and the concepts, terminology and methods associated in the past with one theoretical approach are used and modified in other approaches. 
T. Stryjakiewicz (1999: 24-27) distinguishes three theoretical and methodological orientations in geography of industry, which are now complementary: neoclassical, behavioural and institutional. From the point of view of the subject of research in this publication, institutional orientation ${ }^{1}$ requires a broader discussion. In this theory, in contrast to the neoclassical theory, the goals, priorities and strategies of enterprises are largely autonomous and, being a part of the environment, can be changed considerably and not only passively accepted. Institutional orientation is closely related to geography of enterprise (or corporate geography) developing since the 1960s. "This research direction underlines the role of economic organisations (in particular, large supranational enterprises) as the basic element of shaping the structure and spatial transformation of the entire economy industry. B. Domański (1997) describes it as an underrated current of research in the Polish economic geography" (Stryjakiewicz, 1999: 24-25).

Thus, the issues raised refer, as many authors point out, to the mainstream of geography of industry research (Stryjakiewicz, 2001a; Wieloński, 2003, 2004; Zioło, 2001, 2003, 2004, 2006a, 2006b; Zorska, 1998, 2002, 2007).

\section{RESEARCH PROBLEMS OF CORPORATIONS IN POLISH LITERATURE ON THE SUBJECT}

So far, research into corporations in geography of industry in Poland has focused primarily on the problem of the diversification of the world's industrial space in terms of:

- concentration of head offices, also focusing on the essence of the head office, in which strategic decisions are made for corporations, even if it is significantly distant from the branches these decisions concern. The authors often explain the decision process and the rules of the corporation's operation and their management head offices through example studies of the corporations (Domański, 2002; Gierańczyk, Stańczyk, 2003; Kilar, Cieluch, 2008; Kilar, 2014a, 2014b, 2015, 2016; Sala, 2003, 2005; Śleszyński, 2001a, 2001b, 2002b, 2015; Zioło, 2003, 2006a; Zioło, Piróg, 2002; Tobolska, 2010a, 2010b; Raźniak, Winiarczyk-Raźniak, 2014),

- processes of formation as well as theories and factors of location of production, service and various departments; these are often considerations in which the researchers explain empirical examples of the most important motives that have influenced the location of corporation branches and its formation. In this way, the authors, when referring to the location theory, sometimes consider the spatial diversity of corporations in the world (Gługiewicz, 1997; Spector, 2000; Stryjakiewicz, 2001a, 2001b, 2009a 2009b; Stryjakiewicz, Wajda, 2003; Tkocz, 2003; Wajda, 2003, 2006; Wajda, Zoricic-Wołek, 2003; Wajda, Zalewska, 2003; Budner, 2004; Kostrubiec, 2006; Micek, 2006a, 2006b; Kilar, 2007, 2009c, 2010a, 2010b, 2011a, 2011b, 2014a; Kilar, Cieluch, 2008; Tobolska, 2008a, 2010a, 2008b, 2011, 2014,

\footnotetext{
${ }^{1}$ In the institutional orientation, location factors are not a feature assigned to a given location, but are the subject of various negotiations and persuasions, e.g. labour costs, prices or tax levels. According to the institutional theory, this process is controlled by technostructures, i.e. professional, specialised decision-making entities that undertake various activities, including their responsibility for negotiating, which takes place, for example, in market procedures and transactions and relations between national governments and corporations. The methodological pattern of institutional orientation research is classified as an intensive group and consists in an in-depth analysis of outstanding cases (case study), which according to many authors allows to fully understand the complexity of many processes and their dependence on internal and external conditions.
} 
2017; Zioło, 2009a, 2009b, 2011; Bonar, 2009a, 2009b, 2011; Tkocz, Żydzik, 2010; Boguś, 2011a, 2011b, 2012),

- network connections, which somehow relate to the processes of the formation of corporations and their functioning, but it also includes research on the examples of corporations and networking in the world, as well as theoretical and methodological considerations of the possible effects of network connections (Stryjakiewicz, 2001a, 2001b, 2008; Tkocz, 2003; Wieloński, 2003; Zioło, 2003, 2011; Friedman, 2006; Paszkowski, 2008),

- corporate strategies and their organisational forms, which is a complex research problem; by embedding it in theoretical considerations and showing the spatial dimension of the analysed concepts, on empirical examples, it allows learning and understanding this issue more closely (Sowa, 2006; Tobolska, 2006b, 2017),

- the influence of corporations on international conditions for industrial development in national and regional systems; on the one hand, the conditions necessary for increasing the attractiveness of the area for the location of corporation branches and industry development in a given place are approximated, and the examples of local government activities in this area are mentioned (Tkocz, 2003; Tkocz, Sobala, 2006; Kilar, 2007, 2009a, 2009b, 2014c; Matykowski, Tobolska, 2009; Lizak, 2010; Micek, Działek, Górecki, 2010; Tobolska, 2017) and the surrounding industrial enterprises, because often the location of the corporation's branch in the region poses a challenge for the surrounding enterprises, due to its possible competitiveness, but also gives the opportunity to the organisation to learn (Rachwał, 2003; Wieloński, 2003; Zioło, 2003, 2008; Reśko, 2006; Czapliński, Stawarska, 2010),

- stimulating the process of inflow of foreign direct investments and export links; it is a broad issue that in geographical work, apart from the spatial aspect, is also examined from the perspective of factors that attract FDI and, on the other hand, the expected effects and sizes of investment in the host country (Przybylska, 1998, 1999; Domański, 2002; Rachwał, 2003; Brezdeń, 2006; Gierańczyk, 2006; Komornicki, 2006; Sala, 2006; Tkocz, Sobala, 2006; Tobolska, 2007; Kowalska, 2011),

- the influence of corporations and their branches on the shaping of various industrial sectors, which results, inter alia, from the transfer of broadly understood innovations, e.g. technological or organisational, by a corporation, but also from rapid technological progress (Gierańczyk, 2006; Huculak, 2006; Szmytkowska, 2006; Kilar, 2014a),

- indicating the role of cities in the processes of globalisation and the location of corporations in cities and its effects, which is interesting for some authors, due to the research of the function of the location centres, assuming that they are the control and management centres (Śleszyński, 2002a, 2007; Tobolska, 2010b; Wdowicka, 2012; Raźniak, Dorocki, Winiarczyk-Raźniak, Płaziak, Szymańska, 2016),

- corporate CSR activities, i.e. corporate social responsibility conducted by corporations, manifestations of this responsibility and their effectiveness in various aspects (Kowalska, 2012, 2013, 2018).

In the literature (e.g. economic) corporations are still considered from many other points of view, but the issues presented above are most often captured in a geographical way, that is, in relation to space. Geographical approach to corporate issues gives the opportunity to consider their activities in a wider, complementary way. In most 
cases, the analysed phenomena are provided with figures and maps, especially the issues concerning the diversity of corporations in the world and national space, which more fully illustrates the issues under investigation, e.g. the location of various types of departments and various functions in local and global spatial systems.

The most important source which contains publications in this field in Poland is the academic journal The Studies of the Industrial Geography Commission of the Polish Geographical Society, but some of the research results in geography of industry have been published in the form of various types of monographs.

\section{SUMMARY}

The issue of corporation in geographical literature, as it is apparent from the research, is widely undertaken. a definition of corporations and their delimitation, as well as indication of the position of corporate research in systematics of geography are interesting and current topics from the point of view of both the world economy, domestic and local interests, as well as companies and individuals, and therefore are studied by many researchers. Differentiation of corporate issues in the literature is mainly due to a broad spectrum of the factors influencing the location of the corporation on the one hand, and the effects of its operations, both short-term and long-term, on the other hand.

It seems necessary to continue research into the problems of corporations by Polish geographers of industry, but the apparent shortcomings concern sectoral differentiation of the largest economic entities in the national and regional space. It is to be hoped, therefore, that further research of corporations in the field of geography will continue as both empirical and conceptual studies, in various Polish research centres.

\section{References}

Boguś, M. (2011a). Dynamika potencjału ekonomicznego korporacji ponadnarodowej Google w latach 2001-2009 [The dynamics of the economic potential of the multinational corporation Google in years 2001-2009]. Prace Komisji Geografii Przemysłu Polskiego Towarzystwa Geograficznego [Studies of the Industrial Geography Commission of the Polish Geographical Society], 17, 212-224.

Boguś, M. (2011b). Proces kształtowania się korporacji ponadnarodowej Google [The Formation of the Multinational Corporation Google]. Przedsiębiorczość-Edukacja [EntrepreneurshipEducation], 7, 128-145.

Boguś, M. (2012). Koncentracja przestrzenna działalności gospodarczej korporacji ponadnarodowej Google w latach 2006-2010 [Spatial concentration of the economic activity of the multinational corporation Google in years 2006-2010]. Prace Komisji Geografii Przemysłu Polskiego Towarzystwa Geograficznego [Studies of the Industrial Geography Commission of the Polish Geographical Society], 20, 54-66.

Bonar, P. (2011). Funkcjonowanie korporacji Ericsson w warunkach globalnego kryzysu gospodarczego [Functioning of Ericsson company in the conditions of global economic crisis]. Prace Komisji Geografii Przemysłu Polskiego Towarzystwa Geograficznego [Studies of the Industrial Geography Commission of the Polish Geographical Society], 17, 197-211.

Brezdeń, P. (2006). Uwarunkowania bezpośrednich inwestycji zagranicznych i ich wpływ na umiędzynarodowienie działalności gospodarczej w województwie dolnośląskim. Prace Komisji Geografii Przemysłu Polskiego Towarzystwa Geograficznego [Studies of the Industrial Geography Commission of the Polish Geographical Society], 8, 60-73.

Buckley, P. J., Casson, M. (1976). The Future of Multinational Enterprise. London - Basingstoke: McMillan Press. 
Budner, W. (2004). Lokalizacja przedsiębiorstw. Aspekty ekonomiczno-przestrzenne i środowiskowe [Location of enterprises. Economic, spatial and environmental aspects]. Poznań: Wydawnictwo Akademii Ekonomicznej w Poznaniu.

Czapliński, P., Stawarska, A. (2010). Przejawy procesu globalizacji w sferze produkcji na przykładzie Scania Production Słupsk S. A. [Signs of globalization in production sphere exemplified by Scania Production Słupsk S.A.]. Prace Komisji Geografii Przemysłu Polskiego Towarzystwa Geograficznego [Studies of the Industrial Geography Commission of the Polish Geographical Society], 16, 176-186.

Czarny, E., Kleinert, J. (2004). Firmy wielonarodowe w gospodarce światowej [Multinational companies in the global economy]. In: E. Czarny (ed.). Globalizacja od a do Z [Globalization from a to Z]. Warszawa: Narodowy Bank Polski, 234-258.

Czupiał, J. (1997). Organizacja przedsiębiorstw wielonarodowych [Organization of multinational enterprises]. In: L. Olszewski, J. Mozrzymas (ed.). Struktury przemysłowe w gospodarce. Aspekty ekonomiczne, społeczno-kulturowe i polityczne [Industrial structures in the economy. Economic, socio-cultural and political aspects]. Wrocław: Wydawnictwo Uniwersytetu Wrocławskiego.

Dicken, P. (1992). Global Shift. Internationalization of Economic Activity. New York - London: The Guilford Press.

Domański, B. (1997). Geografia przedsiębiorstw - niedoceniany nurt badań w polskiej geografii ekonomicznej [Geography of enterprises - an undervalued research trend in Polish economic geography]. In: Geografia, człowiek, gospodarka [Geography, man, economy]. Kraków: Uniwersytet Jagielloński, 101-112.

Domański, B. (2002). Zagraniczne inwestycje przemysłowe a obszary metropolitalne w Polsce [Foreign industrial investments and metropolitan areas in Poland]. Prace Komisji Geografii Przemysłu Polskiego Towarzystwa Geograficznego [Studies of the Industrial Geography Commission of the Polish Geographical Society], 4, 9-17.

Dunning, J.H. (1993). Multinational Enterprises and the Global Economy. Workingham: Addison - Wesley.

Friedmann, T.L. (2006). Świat jest płaski. Krótka historia XXI wieku [The world is flat. a Brief History of the 21st Century]. Poznań: Dom Wydawniczy REBIS.

Gierańczyk, W. (2006). Rola przedsiębiorstw w polskiej gospodarce w okresie transformacji ustrojowej. Prace Komisji Geografii Przemysłu Polskiego Towarzystwa Geograficznego [Studies of the Industrial Geography Commission of the Polish Geographical Society], 8, 91-99.

Gierańczyk, W., Stańczyk, A. (2003). Korporacje międzynarodowe w przestrzeni globalnej [International corporations in the global space]. Prace Komisji Geografii Przemysłu Polskiego Towarzystwa Geograficznego [Studies of the Industrial Geography Commission of the Polish Geographical Society], 5, 73-84.

Gługiewicz, E. (1997). Czynniki lokalizacji przedsiębiorstw w Unii Europejskiej - wnioski dla polityki regionalnej. Toruń: Uniwersytet Mikołaja Kopernika.

Griffin, R. (1998). Podstawy zarządzania organizacjami. Warszawa: Wydawnictwo Naukowe PWN.

Hayter, R. (1997). The Dynamics of Industrial Location. The Factory, the Firm and the Producent System. Chichester: John Wiley.

Huculak, M. (2006). Procesy współkształtujące globalizację przemysłu piwowarskiego Europy. Prace Komisji Geografii Przemysłu Polskiego Towarzystwa Geograficznego [Studies of the Industrial Geography Commission of the Polish Geographical Society], 8, 152-159.

Jarczewska-Romaniuk, A. (2004). Przedsiębiorstwa międzynarodowe [International enterprises]. Bydgoszcz-Warszawa: Oficyna Wydawnicza Branta.

Kilar, W. (2007). Zarys kształtowania się korporacji ponadnarodowej Microsoft [The outline of the formation of a transnational corporation Microsoft]. In: I. Kiniorska, S. Sala (ed.). Rola Geografii Społeczno-Ekonomicznej w Badaniach Regionalnych [The role of socio-economic geography in regional research]. Kielce: Instytut Geografii Akademii Świętokrzyskiej im. Jana Kochanowskiego w Kielcach, Oddział Kielecki Polskiego Towarzystwa Geograficznego, 381-389.

Kilar, W. (2009a). Koncentracja przestrzenna światowych firm informatycznych [Spatial concentration of world IT companies]. Prace Komisji Geografii Przemysłu Polskiego Towarzystwa Geograficznego [Studies of the Industrial Geography Commission of the Polish Geographical Society], 12, 97-108. 
Kilar, W. (2009b). Zróżnicowanie potencjału ekonomicznego światowych korporacji informatycznych [Diversification of the economic potential of global IT Corporations]. Prace Komisji Geografii Przemysłu Polskiego Towarzystwa Geograficznego [Studies of the Industrial Geography Commission of the Polish Geographical Society], 13, 110-121.

Kilar, W. (2009c). Rola korporacji Apple w kształtowaniu społeczeństwa informacyjnego [Role of Apple Corporation in Forming Information Society]. Przedsiębiorczość-Edukacja [Entrepreneurship-Education], 5, 48-56.

Kilar, W. (2010a). Procesy kształtowania się korporacji Ericsson [Formation of Ericsson corporation]. Prace Komisji Geografii Przemysłu Polskiego Towarzystwa Geograficznego [Studies of the Industrial Geography Commission of the Polish Geographical Society], 16, 153-168.

Kilar, W. (2010b). Zmiany potencjału korporacji informatycznych w Unii Europejskiej w latach 2004-2008 [Changes in the Potential of IT Corporations in the European Union: years 2004-2008]. Przedsiębiorczość-Edukacja [Entrepreneurship-Education], 6, 49-66.

Kilar, W. (2011a). Wpływ kryzysu na funkcjonowanie korporacji Panasonic [The impact of the crisis on the functioning of Panasonic corporation]. Prace Komisji Geografii Przemysłu Polskiego Towarzystwa Geograficznego [Studies of the Industrial Geography Commission of the Polish Geographical Society], 17, 187-196.

Kilar, W. (2011b). Kształtowanie się Grupy Samsung w warunkach globalizacji [Formation of Samsung Group in the Globalization Era]. Przedsiębiorczość-Edukacja [EntrepreneurshipEducation], 7, 116-127.

Kilar, W. (2014a). Funkcjonowanie korporacji Amazon.com w warunkach kryzysu gospodarczego [The operating of Amazon.com corporation during the economic crisis]. Prace Komisji Geografii Przemysłu Polskiego Towarzystwa Geograficznego [Studies of the Industrial Geography Commission of the Polish Geographical Society], 27, 72-83.

Kilar, W. (2014b). Spatial Concentration of IT Corporation Headquarters. Prace Komisji Geografii Przemysłu Polskiego Towarzystwa Geograficznego [Studies of the Industrial Geography Commission of the Polish Geographical Society], 25, 56-80.

Kilar, W. (2014c). Zmiany potencjału ekonomicznego wybranych korporacji informatycznych $\mathrm{w}$ warunkach kryzysu gospodarczego [Changes in the economic potential of selected information technology corporations in a context of economic crisis]. Prace Komisji Geografii Przemysłu Polskiego Towarzystwa Geograficznego [Studies of the Industrial Geography Commission of the Polish Geographical Society], 27, 57-71.

Kilar, W. (2015). Settlement concentration of economic potential represented by IT corpora-tions. Geographia Polonica, 88(1), 123-141. DOI: 10.7163/GPol.0009

Kilar, W. (2016), Technopolie jako miejsca lokalizacji korporacji informatycznych [Technopoles as Places of the Location of IT Corporations]. Przedsiębiorczość-Edukacja [EntrepreneurshipEducation], 12, 98-113.

Kilar, W., Cieluch M. (2008). Kształtowanie się i organizacja przestrzenna korporacji ponadnarodowej Honda [Formation and spatial organization of the international corporation Honda]. Prace Komisji Geografii Przemysłu Polskiego Towarzystwa Geograficznego [Studies of the Industrial Geography Commission of the Polish Geographical Society], 10, 188-203.

Komornicki, T. (2006). Eksport w ujęciu regionalnym jako miernik rozwoju przemysłu. Prace Komisji Geografii Przemysłu Polskiego Towarzystwa Geograficznego [Studies of the Industrial Geography Commission of the Polish Geographical Society], 8, 167-178.

Kostrubiec, B. (2006). Delokalizacja przedsiębiorstw - przejaw światowej samoregulacji [Relocation of enterprises - a manifestation of global self-regulation]. Prace Komisji Geografii Przemysłu Polskiego Towarzystwa Geograficznego [Studies of the Industrial Geography Commission of the Polish Geographical Society], 8, 37-46.

Kowalska, K. (2011). Możliwości oceny wpływu bezpośrednich inwestycji zagranicznych w handlu na urzeczywistnianie rozwoju lokalnego i regionalnego [The possibilities of estimating the influence of direct foreign investments on trade in local and regional development's aspect]. Prace Komisji Geografii Przemysłu Polskiego Towarzystwa Geograficznego [Studies of the Industrial Geography Commission of the Polish Geographical Society], 18, 83-91.

Kowalska, K. (2012). Społeczna odpowiedzialność międzynarodowych korporacji [Social responsibility of international corporations]. Prace Komisji Geografii Przemysłu Polskiego 
Towarzystwa Geograficznego [Studies of the Industrial Geography Commission of the Polish Geographical Society], 20, 196-202.

Kowalska, K. (2013). Nowoczesny kanał dystrybucji. Współczesne standardy i strategie rozwoju [Modern Channel of Distribution. Contemporary Standards and Development Strategies]. Prace Komisji Geografii Przemysłu Polskiego Towarzystwa Geograficznego [Studies of the Industrial Geography Commission of the Polish Geographical Society], 23, 81-90.

Kowalska, K. (2018). Upowszechnianie praktyk CSR w ramach współpracy międzynarodowych korporacji z lokalnymi firmami kraju przyjmującego [Dissemination of CSR Practices within the Framework of Cooperation Between International Corporations and Local Companies of the Host Country]. Prace Komisji Geografii Przemysłu Polskiego Towarzystwa Geograficznego [Studies of the Industrial Geography Commission of the Polish Geographical Society], 32(2), 142-151.

Kukułka, J. (2000). Teoria stosunków międzynarodowych. Warszawa: Wydawnictwo Naukowe Scholar.

Lizak, P. (2010). Działalność japońskich koncernów motoryzacyjnych na terenie Unii Europejskiej jako wyraz atrakcyjności układów regionalnych [The Activities of Japanese Automotive Companies in the European Union as a Sign of Attractiveness of Regional Arrangements]. Przedsiębiorczość-Edukacja [Entrepreneurship-Education], 6, 66-77.

Marzęda, K. (2007). Proces globalizacji korporacyjnej [The process of corporate globalisation]. Bydgoszcz-Warszawa-Lublin: Oficyna Wydawnicza „Branta”.

Matykowski, R., Tobolska, A. (2009). Funkcjonowanie zakładów przemysłowych XXI wieku na przykładzie Swedwood Poland i Volkswagen Motor Polska Sp. z o.o. Analiza dojazdów do pracy [Operation of 21st-century industrial plants as exemplified by Swedwood Poland and Volkswagen Motor Polska Sp. z o.o.: Analysis of journeys to work]. Prace Komisji Geografii Przemysłu Polskiego Towarzystwa Geograficznego [Studies of the Industrial Geography Commission of the Polish Geographical Society], 14, 66-75.

Micek, G. (2006a). Problematyka funkcjonowania firm informatycznych w ujęciu przestrzennym [Problems of functioning of IT companies in spatial approach]. Prace Komisji Geografii Przemysłu Polskiego Towarzystwa Geograficznego [Studies of the Industrial Geography Commission of the Polish Geographical Society], 8, 139-151.

Micek, G. (2006b). Czynniki i mechanizmy koncentracji przestrzennej firm informatycznych w Polsce. Praca doktorska wykonana w Zakładzie Rozwoju Regionalnego Instytutu Geografii i Gospodarki Przestrzennej Uniwersytetu Jagiellońskiego, Kraków [Factors and mechanisms of spatial concentration of IT companies in Poland. Ph.D. thesis made at the Department of Regional Development of the Institute of Geography and Spatial Management of the Jagiellonian University, Krakow].

Micek, G., Działek, J., Górecki, J. (2010). Centra usług w Krakowie: i ich relacje z otoczeniem lokalnym [Service centres in Krakow and their relations with the local environment]. Kraków: Wydawnictwo Uniwersytetu Jagiellońskiego.

Paszkowski, M. (2008). Kształtująca się gospodarka sieciowa jako pole badawcze geografii przemysłu [Emerging network economy as a research field of geography of production]. Prace Komisji Geografii Przemysłu Polskiego Towarzystwa Geograficznego [Studies of the Industrial Geography Commission of the Polish Geographical Society], 11, 40-45.

Przybylska, K. (1998). Determinanty zagranicznych inwestycji bezpośrednich w teorii międzynarodowego cyklu życia produktu [Determinants of foreign direct investment in the theory of international product life cycle]. Gospodarka Narodowa [National Economy], 2-3, 42-50.

Przybylska, K. (1999). Monopolistyczne przewagi przedsiębiorstw podejmujących bezpośrednie inwestycje bezpośrednie [Monopolistic advantages of enterprises undertaking direct direct investments]. Gospodarka Narodowa [National Economy], 4, 44-55.

Rachwał, T. (2003). Globalne uwarunkowania restrukturyzacji przedsiębiorstw Polski Południowo-Wschodniej [Global conditions of restructuring of South-Eastern Poland enterprises]. Prace Komisji Geografii Przemysłu Polskiego Towarzystwa Geograficznego [Studies of the Industrial Geography Commission of the Polish Geographical Society], 6, 129-138.

Raźniak, P., Dorocki, S., Winiarczyk-Raźniak, A., Płaziak, M., Szymańska, A.I. (2016). Lokalizacja ośrodków kontroli i zarządzania elementem stabilności gospodarczej ośrodków miejskich w Europie Środkowo-Wschodniej [Centres of Command and Control Location as 
an Element of Economic Stability in Urban Centres of Central and Eastern Europe]. Prace Komisji Geografii Przemysłu Polskiego Towarzystwa Geograficznego [Studies of the Industrial Geography Commission of the Polish Geographical Society], 30(2), 38-54.

Raźniak, P., Winiarczyk-Raźniak, A. (2014). Sytuacja finansowa korporacji europejskich w dobie kryzysu [The financial condition of European corporations during the economic crisis]. Prace Komisji Geografii Przemysłu Polskiego Towarzystwa Geograficznego [Studies of the Industrial Geography Commission of the Polish Geographical Society], 27, 99-117.

Reśko, D. (2006). Funkcjonowanie małych i średnich przedsiębiorstw w otoczeniu międzynarodowym. Prace Komisji Geografii Przemysłu Polskiego Towarzystwa Geograficznego [Studies of the Industrial Geography Commission of the Polish Geographical Society], 8, 115-126.

Sala, S. (2003). Wybrane cechy działalności korporacji transnarodowych i ich implikacje dla Polski [Selected features of transnational corporation's activities and their implications for Poland]. Prace Komisji Geografii Przemysłu Polskiego Towarzystwa Geograficznego [Studies of the Industrial Geography Commission of the Polish Geographical Society], 6, 101-108.

Sala, S. (2005). Rozwój korporacji transnarodowych w gospodarce światowej [The development of transnational corporations in the global economy]. Przedsiębiorczość - Edukacja [Entrepreneurship-Education], 1, 33-44.

Sala, S. (2006). Bezpośrednie inwestycje zagraniczne a procesy globalizacji [Foreign direct investments and globalisation processes]. Prace Komisji Geografii Przemysłu Polskiego Towarzystwa Geograficznego [Studies of the Industrial Geography Commission of the Polish Geographical Society], 8, 80-90.

Sowa, K. (2006). Strategie konkurencji korporacji ponadnarodowych [Competition strategies of supranational corporations]. Warszawa: Centrum Doradztwa i Informacji Difin.

Spector, R. (2000). Amazon.com. Historia przedsiębiorstwa, które stworzyło nowy model biznesu [Amazon.com. The history of the company that created a new business model]. Warszawa: Wydawnictwo K.E. LIBER.

Stryjakiewicz, T. (1999). Adaptacja przestrzenna przemysłu $w$ Polsce $w$ warunkach transformacji [Spatial adaptation of industry in Poland under transformation conditions]. Poznań: Wydawnictwo Naukowe Uniwersytetu im. A. Mickiewicza.

Stryjakiewicz, T. (2001a). Koncepcja usieciowienia (networking) w badaniach przestrzenno - ekonomicznych [The concept of networking in spatial and economic research]. In: H. Rogacki (ed.). Koncepcje teoretyczne i metody badań geografii społeczno - ekonomicznej i gospodarki przestrzennej [Theoretical concepts and methods of research on socio-economic geography and spatial planning]. Poznań: Bogucki Wydawnictwo Naukowe, 37-47.

Stryjakiewicz, T. (2001b). Orientacje teoretyczno-metodologiczne w geografii przemysłu a transformacja gospodarki [Theoretical and methodological orientations in the geography of industry and the transformation of the economy]. Prace Komisji Geografii Przemysłu Polskiego Towarzystwa Geograficznego [Studies of the Industrial Geography Commission of the Polish Geographical Society], 3, 13-27.

Stryjakiewicz, T. (2008). GlaxoSmithKline. Regional and local networking in post-communist economy. In: P. Pellenbarg, E. Wever (ed.). International business Geography. Case studies of corporate firms. Routledge: Taylor and Francis Group, Oxon, 260-275.

Stryjakiewicz, T. (2009a). Nowe spojrzenie na czynniki lokalizacji działalności gospodarczej [A new look at the factors of business location]. In: Współczesne problemy przemian strukturalnych przestrzeni geograficznej [Contemporary problems of structural changes in geographical space]. Słupsk, 94-102.

Stryjakiewicz, T. (2009b). Lokalizacja firm i zachowania przestrzenne pracowników sektora informatycznego (na przykładzie poznańskiego obszaru metropolitalnego) [Location of firms and spatial behaviour of employees of the IT sector (the case of the Poznań metropolitan area)]. Prace Komisji Geografii Przemysłu Polskiego Towarzystwa Geograficznego [Studies of the Industrial Geography Commission of the Polish Geographical Society], 13, 21-33.

Stryjakiewicz, T., Wajda J. (2003). Organizacja przestrzenna grup kapitałowych jako problem badawczy geografii ekonomicznej [Spatial organisation of capital groups as a research problem of economic geography]. Prace Komisji Geografii Przemysłu Polskiego Towarzystwa Geograficznego [Studies of the Industrial Geography Commission of the Polish Geographical Society], 6, 27-48. 
Szmytkowska, M. (2006). Rozwój sektora teleinformatycznego w Trójmieście jako przejaw procesów globalizacji [Development of the ICT sector in the Tri-City as a manifestation of globalisation processes]. Prace Komisji Geografii Przemysłu Polskiego Towarzystwa Geograficznego [Studies of the Industrial Geography Commission of the Polish Geographical Society], 8, 160-166.

Śleszyński, P. (2001a). Rozmieszczenie głównych siedzib ważniejszych przedsiębiorstw w Warszawie w 1999 r. [Distribution of head offices of major enterprises in Warsaw in 1999]. In: XV Konwersatorium Wiedzy o Mieście [XV Seminar of Knowledge about the City]. Łódź: Katedra Geografii Miast i Turyzmu Uniwersytetu Łódzkiego, Komisja Geografii Osadnictwa i Ludności Polskiego Towarzystwa Geograficznego, Łódzkie Towarzystwo Naukowe, 311-323.

Śleszyński, P. (2001b). Lokalizacja głównych siedzib przedsiębiorstw w przestrzeni Warszawy w końcu lat 90. Czynniki i bariery regionalnej współpracy transgranicznej - bilans dokonań [Location of the main company head offices in the Warsaw space at the end of the 1990s. Factors and barriers to regional cross-border cooperation - a balance of achievements]. 50. Zjazd Polskiego Towarzystwa Geograficznego, Oddział Rzeszowski [50. Congress of the Polish Geographical Society, Rzeszów Branch]. Rzeszów: Polskie Towarzystwo Geograficzne, UMCS - Filia w Rzeszowie, Uniwersytet Rzeszowski, 106-111.

Śleszyński, P. (2002a). Struktura i rozmieszczenie ośrodków zarządzania w polskiej gospodarce w 2000 r. [Structure and distribution of management centres in the Polish economy in 2000]. Prace Komisji Geografii Przemysłu Polskiego Towarzystwa Geograficznego [Studies of the Industrial Geography Commission of the Polish Geographical Society], 2, 199-228.

Śleszyński, P. (2002b). Struktura i koncentracja przestrzenna siedzib ważniejszych przedsiębiorstw w Warszawie w 1999 roku [Structure and spatial concentration of head offices of major enterprises in Warsaw in 1999]. Prace Komisji Geografii Przemysłu Polskiego Towarzystwa Geograficznego [Studies of the Industrial Geography Commission of the Polish Geographical Society], 4, 89-114.

Śleszyński, P. (2007). Gospodarcze funkcje kontrolne w przestrzeni Polski [Economic control functions in the space of Poland]. Warszawa: Instytut Geografii i Przestrzennego Zagospodarowania Polskiej Akademii Nauk.

Śleszyński, P. (2015). Economic control functions in Poland in 2013. Geographia Polonica, 88(4), 701-708.

Tkocz, M. (2003). Przejawy procesu globalizacji w przemyśle województwa śląskiego [The manifestations of the globalisation process in the industry of Śląskie Voivodeship]. Prace Komisji Geografii Przemysłu Polskiego Towarzystwa Geograficznego [Studies of the Industrial Geography Commission of the Polish Geographical Society], 6, 67-76.

Tkocz, M., Sobala, O. (2006). Kapitał zagraniczny w przemianach gospodarczych tradycyjnego ośrodka przemysłowego na przykładzie Chorzowa [Foreign capital in economic changes of a traditional industrial centre on the example of Chorzów]. Prace Komisji Geografii Przemysłu Polskiego Towarzystwa Geograficznego [Studies of the Industrial Geography Commission of the Polish Geographical Society], 8, 74-79.

Tkocz, M., Żydzik, J. (2010). Rola światowego koncernu w przemianach przestrzeni przemysłowej Polski w okresie transformacji na przykładzie The Coca-Cola Company [Role of a world-wide company in changes of industrial space of Poland in the transformation period, with special reference to the Coca-Cola Company]. Prace Komisji Geografii Przemysłu Polskiego Towarzystwa Geograficznego [Studies of the Industrial Geography Commission of the Polish Geographical Society], 16, 169-175.

Tobolska, A. (2006a). Nowy model organizacji i funkcjonowania starych przedsiębiorstw przemysłowych [A new model of the organisation and operation of old industrial enterprises]. Prace Komisji Geografii Przemysłu Polskiego Towarzystwa Geograficznego [Studies of the Industrial Geography Commission of the Polish Geographical Society], 9, 83-97.

Tobolska, A. (2006b). Strategie globalne a nowe formy organizacji przedsiębiorstw transnarodowych [Global Strategies and New Organisational Forms of Transnational Enterprises]. Przedsiębiorczość-Edukacja [Entrepreneurship-Education], 2, 125-142.

Tobolska, A. (2007a). Bezpośrednie inwestycje zagraniczne a internacjonalizacja przemysłu polskiego [Direct foreign investments and the internationalisation of the Polish industry]. 
In: J. Lach, M. Borowiec, T. Rachwał (ed.). Procesy transformacji społeczno-ekonomicznych i przyrodniczych struktur przestrzennych [Processes of transformation of socio-economic and natural spatial structures]. Kraków: Wydawnictwo Naukowe Akademii Pedgogicznej w Krakowie, 242-256.

Tobolska, A. (2008a). Przestrzenne aspekty ekspansji zagranicznej korporacji międzynarodowych w koncepcjach internacjonalizacji [Spatial aspects of the expansion of foreign international corporations in the concepts of internationalisation]. Rozwój Regionalny i Polityka Regionalna, 3, 89-113.

Tobolska, A. (2008b.). Wpływ koncernów międzynarodowych na środowisko naturalne w Polsce na przykładzie Swedwood Poland sp. z o.o. w Chlastawie [The influence of international corporations on the natural environment in Poland on the example of Swedwood Poland Ltd. in Chlastawa]. Dokumentacja Geograficzna, 37, 136-143.

Tobolska, A. (2010a). Koncepcje teoretyczne wyjaśniające zachowania korporacji międzynarodowych - wymiar przestrzenny [Theoretical concepts explaining the behaviour of international corporations - spatial dimension]. Ekonomista [Economist], 2, 243-258.

Tobolska, A. (2010b.). Commuting as a spatial feature of international concern's location in a major city. Example of Poznań. Bulletin of Geography. Socio-economic Series, 13, 5-17.

Tobolska, A. (2011). Czynniki lokalizacji fabryk wybranych korporacji międzynarodowych w Polsce [Factors for the location of factories of selected international corporations in Poland]. Rozwój Regionalny i Polityka Regionalna, 15, 55-67.

Tobolska, A. (2014). Choice of Locations by Foreign Investors: Motives for and Factors of Starting a Manufacturing Activity (the Example of Selected Factories in Poland). Prace Komisji Geografii Przemysłu Polskiego Towarzystwa Geograficznego [Studies of the Industrial Geography Commission of the Polish Geographical Society], 25, 230-251.

Tobolska, A. (2017). Strategie przedsiębiorstw międzynarodowych oraz ich oddziaływania $\mathrm{w}$ przestrzeni lokalnej i regionalnej [Strategies of international enterprises and their impact in the area of the local and regional]. Poznań: Wydawnictwo Naukowe Uniwersytetu Adama Mickiewicza.

Tobolska, A., Matykowski, R. (2006). Działalność przemysłowa w warunkach wzrastającej internacjonalizacji i globalizacji na przykładzie wybranych produktów [Industrial activity in the conditions of increasing internationalisation and globalisation on the example of selected products]. Prace Komisji Geografii Przemysłu Polskiego Towarzystwa Geograficznego [Studies of the Industrial Geography Commission of the Polish Geographical Society], 8, 47-59.

Towarnicka, H. (1997). Wybory strategiczne przedsiębiorstwa prowadzącego działalność zagraniczną [Strategic choices of a company operating abroad]. In: M. Nowakowski (ed.). Bariery internacjonalizacji przedsiębiorstwa [The barriers to the internationalisation of the enterprise]. Warszawa: Wydawnictwo Key Text.

Wajda, E. (2003). Proces kształtowania się Motoroli jako firmy ponadnarodowej [The process of shaping Motorola as a supranational company]. Prace Komisji Geografii Przemysłu Polskiego Towarzystwa Geograficznego [Studies of the Industrial Geography Commission of the Polish Geographical Society], 5, 85-114.

Wajda, E. (2006). Rozwój i struktura przestrzenna działalności Noki w latach 1997-2003 [Development and spatial structure of Nokia's activities in 1997-2003]. Prace Komisji Geografii Przemysłu Polskiego Towarzystwa Geograficznego [Studies of the Industrial Geography Commission of the Polish Geographical Society], 8, 219-240.

Wajda, E., Zalewska, K. (2003). Struktura przestrzenno-organizacyjna korporacji General Motors [Spatial and organisational structure of General Motors corporation]. Prace Komisji Geografii Przemysłu Polskiego Towarzystwa Geograficznego [Studies of the Industrial Geography Commission of the Polish Geographical Society], 6, 119-128.

Wajda, E., Zoričič-Wołek, M. (2003). Proces kształtowania się korporacji [The process of corporate formation]. Prace Komisji Geografii Przemysłu Polskiego Towarzystwa Geograficznego [Studies of the Industrial Geography Commission of the Polish Geographical Society], 6, 109-118.

Wdowicka, M. (2012). Miasta w dobie globalizacji: korporacje transnarodowe w polskich miastach a dostępność nowoczesnej przestrzeni dla biznesu. Studia miejskie, 5, 103-113. 
Wieloński, A. (2003). Przemysł Nowej Gospodarki [Industry of the New Economy]. Prace Komisji Geografii Przemysłu Polskiego Towarzystwa Geograficznego [Studies of the Industrial Geography Commission of the Polish Geographical Society], 6, 21-26.

Wieloński, A. (2004). Lokalizacja działalności gospodarczej. Teoretyczne podstawy [Location of the business. Theoretical foundations]. Warszawa: Uniwersytet Warszawski, Wydział Geografii i Studiów Regionalnych, Wydawnictwo Przemysłowe WEMA Sp. z o.o.

World Investment Report (2001). WIR 2001 - Promoting Linkages. New York, Geneva: UNCTAD United Nations.

World Investment Report (2005). WIR 2005 - Transnational Corporations and the Internationalization of R\&D. New York and Geneva: UNCTAD United Nations.

World Investment Report (2006). WIR 2006 - FDI from Developing and Transition Economies: Implications for Development. New York and Geneva: UNCTAD United Nations.

Zioło, Z. (2001). Struktura branżowa i koncentracja przestrzenna wiodących światowych firm przemysłowych [Branch structure and spatial concentration of leading global industrial companies]. Prace Komisji Geografii Przemysłu Polskiego Towarzystwa Geograficznego [Studies of the Industrial Geography Commission of the Polish Geographical Society], 3, 29-41.

Zioło, Z. (2003). Kształtowanie się przedsiębiorstw przemysłowych w procesie globalizacji [The formation of industrial enterprises in the globalisation process]. Prace Komisji Geografii Przemysłu Polskiego Towarzystwa Geograficznego [Studies of the Industrial Geography Commission of the Polish Geographical Society], 6, 9-20.

Zioło, Z. (2004). Kształtowanie się firm informatycznych jako nowych elementów struktury przestrzennej przemysłu [The formation of IT companies as new elements of the spatial structure of industry]. Prace Komisji Geografii Przemysłu Polskiego Towarzystwa Geograficznego [Studies of the Industrial Geography Commission of the Polish Geographical Society], 7, 97-106.

Zioło, Z. (2006a). Zróżnicowanie światowej przestrzeni przemysłowej w świetle koncentracji siedzib zarządów wiodących korporacji [Diversification of the global industrial space in the light of the concentration of head offices of leading corporations]. Prace Komisji Geografii Przemysłu Polskiego Towarzystwa Geograficznego [Studies of the Industrial Geography Commission of the Polish Geographical Society], 8, 9-26.

Zioło, Z. (2006b). Potencjał ekonomiczny wiodących światowych miast na przełomie wieków [The economic potential of the world's leading cities at the turn of the century]. In: B. Górz (ed.). Urbanizacja i społeczeństwo [Urbanisation and society]. Kraków: Instytut Geografii Akademii Pedagogicznej w Krakowie, 67-95.

Zioło, Z. (2008). Procesy transformacji przemysłowych układów przestrzennych na tle zmieniającego się otoczenia [ransformational processes in industrial spatial structures in relation to changing surroundings]. Prace Komisji Geografii Przemysłu Polskiego Towarzystwa Geograficznego [Studies of the Industrial Geography Commission of the Polish Geographical Society], 10, 11-22.

Zioło, Z. (2009a). Procesy kształtowania się światowych korporacji i ich wpływ na otoczenie [Global corporations' shaping processes and influence on their environment]. Prace Komisji Geografii Przemysłu Polskiego Towarzystwa Geograficznego [Studies of the Industrial Geography Commission of the Polish Geographical Society], 12, 11-32.

Zioło, Z. (2009b). Rola przemysłu w procesie kształtowania społeczeństwa informacyjnego [Role of industry in the shaping of an information society]. Prace Komisji Geografii Przemystu Polskiego Towarzystwa Geograficznego [Studies of the Industrial Geography Commission of the Polish Geographical Society], 13, 11-20.

Zioło, Z. (2011). Wpływ światowego kryzysu na tempo wzrostu gospodarki i światowych korporacji [The impact of global crisis on functioning of the economy and global corporations]. Prace Komisji Geografii Przemysłu Polskiego Towarzystwa Geograficznego [Studies of the Industrial Geography Commission of the Polish Geographical Society], 17, 9-32.

Zioło, Z., Piróg, S. (2002). Lokalizacja zarządów i potencjał ekonomiczny wiodących firm zachodnioeuropejskich [Location of management boards and economic potential of leading Western European companies]. Prace Komisji Geografii Przemysłu Polskiego Towarzystwa Geograficznego [Studies of the Industrial Geography Commission of the Polish Geographical Society], 4, 25-36. 
Zorska, A. 1998 (2002). Ku globalizacji? Przemiany w korporacjach transnarodowych $i$ w gospodarce światowej [Towards globalisation? Transformation in transnational corporations and in the global economy]. Warszawa: Wydawnictwo Naukowe PWN.

Zorska, A. (2002). Korporacje międzynarodowe w Polsce. Wyzwania w dobie globalizacji i regionalizacji [International corporations in Poland. Challenges in the era of globalisation and regionalisation]. Warszawa: Difin.

Zorska, A. (2007). Korporacje transnarodowe. Przemiany, oddziaływania, wyzwania [Transnational corporations. Transformations, impacts, challenges]. Warszawa: Polskie Wydawnictwo ekonomiczne.

Wioletta Kilar, Ph.D., Pedagogical University of Cracow, Institute of Geography, Department of Entrepreneurship and Spatial Management. She is an economic geographer. Her research interests focus primarily on the processes of formation and operation of multinational corporations, globalisation, transformation of spatial structures of industry, and issues of teaching Entrepreneurship and Geography in schools.

\section{Address:}

Pedagogical University of Cracow Institute of Geography

Department of Entrepreneurship and Spatial Management

ul. Podchorążych 2, 30-084 Kraków, Poland

e-mail:Wioletta.Kilar@up.krakow.pl 